\title{
An Analysis of Communication Strategies in Speaking
}

\author{
N.L.A. Widiastuti ${ }^{1 *}$, D.K. Tantra ${ }^{2 *}$, N.Y. Padmadewi ${ }^{3 *}$ (D) \\ 1,2,3 English Language Ganesha University of Education, Bali, Indonesia
}

\section{A R T I C L E I N F O}

Article history:

Received February 17, 202

Revised February 20, 2021

Accepted June 17, 2021

Available online August 25, 2021

Kata Kunci:

Berbahasa Inggris,

Kurikulum 2013, Strategi

Komunikasi

Keywords:

Communication

Strategies, Curriculum

2013, English speaking

DOI:

http://dx.doi.org/10.23887/jpbi.v $\underline{9 \mathrm{i} 2.32319}$

\begin{abstract}
A B S T R A K
Pendekatan Ilmiah dalam proses pembelajaran. Dalam menerapkan lima prosedur utama Pendekatan Ilmiah dalam kegiatan pembelajaran peneliti masih menemukan beberapa masalah. Rincian kegiatan harus sesuai dengan tahapan Pendekatan Ilmiah. Tujuan penelitian ini adalah untuk menganalisis strategi komunikasi siswa SMP ketika diajar oleh guru bahasa Inggris selama kelas berbicara di SMP yang menerapkan Kurikulum 2013. Jenis penelitian ini yaitu kualitatif dengan menggunakan desain kualitatif. Pengumpulan data dilakukan melalui observasi langsung. Dalam pengumpulan data, penelitian menggunakan perekam seluler. Selain itu lembar observasi juga digunakan untuk memperoleh data. Data yang diambil dianalisis secara deskriptif. Hasil penelitian ini menunjukkan bahwa guru menerapkan 15 dimensi Strategi Komunikasi, yaitu Terjemahan Literal, Code Switching, Pantomim, Pengurangan Pesan, Penggantian Pesan, Pengulangan, Penggunaan Pengisi, Pembuat Strategi Verba, Akurasi Sendiri, Respons, Menanyakan Klarifikasi, Meminta Konfirmasi, Mengajukan Bantuan, Meminta Pengulangan, dan Pemeriksaan Pemahaman. Dari 15 strategi yang diterapkan, Respon memiliki persentase kejadian tertinggi. sekitar $23.72 \%$. Sedangkan siswa hanya menggunakan tujuh dimensi Strategi Komunikasi. Itu adalah pepatah Retrieval, Perbaikan Diri, Pantomim, Pengalihan Kode, Penggunaan Pengisi, Mengekspresikan Ketidakpahaman, dan Meminta Pengulangan, dan Pantomim memiliki persentase kejadian tertinggi. Itu $34.21 \%$ kejadian.
\end{abstract}

\section{A B S T R A C T}

The scientific approach in the learning process. There are still some problems in applying the five main procedures of the Scientific Approach in learning activities. Activities must be by the stages of the Scientific Approach. This study aimed to analyze the type of communication between junior high school students during speaking class in junior high school who applied the 2013 curriculum. This study was qualitative using a qualitative design. Data collection is done through direct observation. In data collection, the study used a cellular recorder. In addition, observation sheets were also used to obtain data. Data were taken descriptively. The results of this study indicate that the teacher applies a 15-dimensional Communication Strategy, namely Literal Translation, Code Switching, Pantomime, Message Reduction, Message Substitution, Repetition, Use of Fillers, Verb Strategy Maker, Self Accuracy, Response, Asking Clarification, Asking for Confirmation, Asking for Help, Repetition Request, and Comprehension Comprehension. Of the 15 strategies applied, Response has the highest proportion of events around $23.72 \%$. Meanwhile, students only use seven dimensions of Communication Strategy. Those are Self-Improvement, Self-Improvement, Pantomime, Code Switching, Use of Fillers, Expressing Disappointment, Explanation of Repetition, Pantomime has the highest occurrence. That is a $34.21 \%$ occurrence.

This is an open-access article under the CC BY-SA license. Copyright (C) 2021 by Author. Published by Universitas Pendidikan Ganesha.

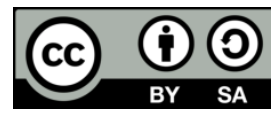

\section{INTRODUCTION}

The learning process in the 2013 Curriculum is not only focused on the knowledge and focused on the skills and the affective domain (Sadaf \& Johnson, 2017; Winatha et al., 2018). The learning activities that apply the scientific approach are designed in five main procedures: observing, questioning, exploring, associating, and communicating (Davidi et al., 2021; Salim Nahdi \& Cahyaningsih, 2018). By integrating those five main procedures, the students will change their role from passive participants who only listen to the teacher's explanation to active participants. It means that the students not only listen to the teacher's description, but they also required to involve themselves in the learning process by reading, writing, speaking, and discussing or being engaged in solving the problem and gaining knowledge (Dumitrescu et al., 2014; Sutarto, 2017).

English as the Foreign Language in 2013 Curriculum has several skills that should be taught in the learning process in 2013 Curriculum such as reading, writing, listening, and speaking (Kusumawati et al., 2017). In this research, the writers tend to focus on the speaking skills during the learning process as speaking is one of the essential skills in language learning, and it is the key to active communication (Liyana \& Kurniawan, 2019; 
Sharif Matthews \& López, 2019). However, the current problem is that many children still lack English language skills (Yusnidar, 2014). Students find it difficult to memorize every word in English (Megawati, 2016).

Based on the preliminary observation in one of the junior high schools in Singaraja, the researcher found that the teacher implemented and integrated the Scientific Approach in the learning process. In implementing the five main procedures of the Scientific Approach in the learning activity, the researcher found several problems. The details of the activities should be following the stages of the Scientific Approach in which the first stage is Observation, the second is Question, the third is Exploration, and then continued by Association, and the last is Communication. It is often found that the teacher sometimes does not apply the procedures well. The researcher observed that the teacher sometimes missed several stages. In the 2013 Curriculum, the students must become active participants in the classroom and follow the teacher's instruction during the lesson.

The second problem that the researcher often finds is communicating each of the learning phases in the 2013 Curriculum. There are still several problems encountered, such as the students who are not fully engaged in the classroom and the communication that sometimes goes in one-way communication. The teacher should communicate the lesson well and use appropriate communication strategies to motivate the students to be active. Communication is the act of transferring information from one person to another person. In terms of education and learning, communication can be formulated as the teacher's actions in sharing the knowledge to the students (Mills et al., 2021; Wonodipho, 2019). In teaching and learning, communication is essential to be done by the teacher and the students because communication is the act of transferring knowledge from the teacher and the students or vice versa (Wungguli \& Yahya, 2020; Zhang, 2021). The teacher will also communicate the teaching and learning goals by sharing and explaining the teaching material to the students. In the interaction process, the students use a communication strategy in responding to the teacher (Nordin, 2015; Setiyani et al., 2020).

In terms of how to communicate, communication can be divided into three types: verbal communication, non-verbal communication, and written communication (Indah Perawansa et al., 2019; Madleň́k, 2015). Verbal communication means communication that uses spoken words to communicate the message (Achim et al., 2021). Non-verbal communication includes body language, gestures, facial expressions, or postures (Harrison, 2021). Non-verbal communication can set the tone of communication. At the same time, written communication is the communication that is essential for communicating complicated situations such as statistics or data. Written communication is used when verbal communication cannot fully convey the intended message. In the learning process, the three types of communication can be used by both the teacher and the students. In using every kind of communication, specific strategies can be applied to help the communicator convey the message (Atabekova et al., 2021; Saddhono et al., 2019). The strategies employed by a speaker to get the message and express their meaning when faced with some difficulties are called communication strategies (Nordin, 2015; Wungguli \& Yahya, 2020). The teaching and learning process that aims to transfer and receive knowledge between the teacher and the students would require a communication strategy.

Several researchers have raised the topic of communication strategy in the learning process. The study showed that the students use several communication strategies to overcome difficulties (Ao et al., 2019; Paul et al., 2020). Based on research results, the students are likely to use different communication strategies to convey their intended idea and remain in communication (Kembara et al., 2018; Nakanishi et al., 2019). In this research, the researcher is interested in raising the same topic about communication strategy used in the learning process. The difference from the study that other researchers did lies in the curriculum used in the learning process. The researcher emphasizes on the use of communication strategies in speaking based on 2013 Curriculum. In this research the researcher is interested in investigating the communication strategies used by the teacher and the students in speaking class based on 2013 curriculum. The purpose of this study was to analyze the communication strategies of junior high school students when taught by an English teacher during speaking class at SMP Negeri 1 Singaraja who applied the 2013 Curriculum.

\section{METHOD}

The research was a descriptive qualitative study. It is observational research that involves the researcher in observing the subject of the study. The research was conducted at SMPN 1 Singaraja. The topics of the study were the teacher and the students in SMP N 1 Singaraja. The reason for choosing the eighth class is because the eighth class has a learning experience based on the 2013 curriculum. The data collection process is related to how the data are collected to reach the purpose of the study. In managing the data, the researcher conducted several procedures, namely; Asking permission (Before collecting the data, the researcher visited the headmaster of SMP N 1 Singaraja for asking permission to conduct research or observation in that place.), Statement (In collecting the data for this study, the researcher collected the data by conducting observation, and the data were recorded in the observation sheet.), Collecting some photos or video recorder (During the process of collecting the data, the researcher also took some photos or video recorder when the teacher communicated with students during the learning activity.), Note-taking (In the process of data collection, there were several essential things found by the 
researcher, so that the researcher prepared the field note to take some notes about the crucial things found during the observation.), and Transcribing and analyzing the data (The researcher transcribed and analyzed the data collected through the observation checklist, recording the video and note.)

To understand the data found while gathering the data, the researcher needs to analyze the data using the specific procedures and techniques following the method (Prihandoko et al., 2017). It also stated that the process of data analysis involves data collection, data reduction, data display, and verification. The first step of data collection is classroom observation. The classroom observation was conducted to record the learning activities and fill the data based on the observation sheet. After that, the interview was conducted with the teacher and the students guided by the interview guideline. In this research, the number of data was noted in detail. The complex and complicated data were reduced by summarizing, choosing subject matters, and focusing on the essential things. The obtained data was sorted by eliminating the data which is inappropriate with the purpose of the study. The obtained data were categorized based on their form and types.

The data were displayed and categorized with the same data which are obtained from the same problem. The temporary conclusion was taken from the data reduction. The information was simplified by classifying them into the scientific stages and based on the theory used. The verification is the process of concluding the obtained data to answer the research problem. The obtained data were analyzed, while observation and interview are the tools to get the data. This study used data triangulation to achieve the validity and reliability of data. The data were collected not only through direct observation but also through a data recorder. By using observation and another data collection method, the validity and reliability of data research could be achieved.

\section{RESULT AND DISCUSSION}

Result

In this research, the teacher's communication strategy is defined as EFL teacher's communication techniques implemented during the speaking class based on the 2013 Curriculum at the eighth grade in the State Junior Secondary School 1 Singaraja. After observing the two different courses from the beginning to the end, the following data were gathered in the pre-activity, while-activity, and post-activity. Based on the results of data analysis, there were 15 types implemented by the teacher, and there were 18 types of Communication strategies that were not executed during the teaching process. The highest system implemented by the teacher was Responses (23.72\%), and the second strategy implemented was Code Switching (21.79\%) and followed by Repetition (16.67\%). After that, it was followed by Literal Translation (13.46\%) and Mime (7.05\%) of occurrences. The other percentage of affairs was Comprehension Check (5.77\%) and Asking for Confirmation (2.56\%). The other portion of circumstances was Use of Fillers (1.92\%), Asking for Clarification (1.92\%), Message Replacement (1.28\%), Asking for Repetition (1.28\%), Message Reduction (0.64\%), Verbal Strategy Marker (0.64\%), Appeals for Help $(0.64 \%)$ and Own Accuracy $(0.64 \%)$. Then the other percentage of occurrences $(0,00 \%)$ was Message Abandonment, Circumlocution, Approximation, Use of all-purpose, Word Coinage, Restructuring, Foreignizing, Use of Similar Sounding Words, Mumbling, Omission, Retrieval Saying, Self-rephrasing, Self-repair, Feigning Understanding, Guessing, expressing nonunderstanding, and Interpretive Summary, in which all of those types of Communication Strategy did not implement by the teacher.

Based on the results of data analysis, there were only 7 Communication Strategies used by the students, and 25 Communication Strategies did not implement during the class. The students' highest frequency of Communication Strategies during the course was Mime (34.21\%), followed by fillers (26.32\%). The following frequency of Communication Strategy used by the students was Self-Repair (15.79\%), Retrieval (13.16\%), and Expressing Non-Understanding (5.26\%). Than Asking for Repetition and Foreignizing had $2.63 \%$ of occurrences. In this study, the researcher investigated the teacher's communication strategies and used by the students in speaking class at SMP Negeri 1 Singaraja.

\section{Discussion}

The taxonomy of communication strategies used by the teacher is proposed by Dornyei and Scott (1997). The researcher applied this taxonomy was because Dornyei and Scott have complex types rather than the other taxonomy. There are three types of communication strategies: Direct Strategies, Indirect Strategies, and Interactional Strategies (J. Y. H. Chan, 2021; Rafik-Galea et al., 2012). The direct approach consists of 18 dimensions (message abandonment, message reduction, message replacement, circumlocution, approximation, use of all-purpose word, word-coinage, restructuring, literal translation, foreignizing, code-switching, use of similarsounding words, mumbling, omission, retrieval saying, mime, self-rephrasing, and self-repair). Indirect strategies consist of four dimensions (use of fillers, repetition, verbal strategy maker, and feigning understanding. And the last interactional approach consists of ten sizes (appeals for help, comprehension check, own-accuracy check, 
asking for repetition, asking for clarification, asking for confirmation, guessing, expressing non-understanding, interpretive summary, and responses) (Coffelt et al., 2019; Yaniawati et al., 2019).

From the result of the observation that has been stated in the findings, in which the phase of the teaching process has been divided into three-phase (Pre-Activity, during Activity, and Post Activity), the results showed that in Pre-activity the teacher implemented six sub-categories of Communication strategies from the three types of CS. The six sub-categories mentioned above were three sub-categories from Direct Strategies (Message Replacement, Mime, and Literal Translation), one sub-category of Indirect Strategy (Repetition), and two categories of Interactional Strategies (Comprehension Check and Responses). The Communication Strategies implemented in Pre-activity were executed by the teacher when the teacher did apperception before starting the teaching process and conveyed the learning competence or the activity plan. For example, when the teacher did apperception, the teacher implemented Literal translation, e.g. "So what verb do you know? Verb apa yang masih kalian ingat?". Literal Translation means translating a lexical item, an idiom, a compound word, or structure. From the example of utterance stated above, it is shown that at first, the teacher asked the students in English then translated the exclamation expressed before into Bahasa \{Formatting Citation\}. That kind of strategy means that the teacher emphasized the purpose and meaning of the words (Filgona et al., 2017; Simatupang et al., 2020). Besides Literal Translation, Message Replacement and mime were also the Communication Strategies implemented when the teacher did apperception before the teaching process started (C. S. C. Chan, 2021; Subandi et al., 2018). In apperception, the Indirect Strategies which the teacher intensely implements was Repetition. In reminding the students' memory through the lesson and warming up before starting the class, the teacher implemented many repetition strategies (Dwi et al., 2013; Mitchell et al., 2020).

There were four direct strategies, one indirect strategy dimension, and two interactional strategies (Arsy et al., 2020; Kemp, 2017). The dimensions of direct strategies used by the students are code-switching, retrieval saying, mime, and self-repair. The size of indirect strategies used by the students was the use of fillers. And the last the dimensions of interactional strategies used by the students were asking for repetition and expressing nonunderstanding. Based on the data displayed in the findings above, it is shown that in Pre-Activity, the students only used the Mime strategy as part of Direct strategies. The students gave a response to the teacher utterance only by non-verbal expression. They were using the non-verbal strategy in place of lexical items such as gestures, mime, facial expression, or sound imitation (Harrison, 2021; Putri, 2018). At that situation, when the teacher conveyed something to the students for example, when the teacher asked the students to write down something, the students were not responding by saying anything but they only responded by using gestures such as the students directly wrote down what was commanded by the teacher (Morgan et al., 2021; Nugraha et al., 2016).

The teacher implemented 15 dimensions of Communication Strategies. From the 15 strategies implemented by the teacher, the teacher's highest occurrences of the strategy were Responses. The students used seven dimensions of Communication Strategy; dimension Communication Strategy used by the students were Retrieval saying, Self-Repair, Mime, Code Switching, Use Of Fillers, Expressing Non-Understanding, and Asking For Repetition. Suggestion for the teacher (The teacher is expected to enrich the knowledge about Communication Strategy, which can be used during the teaching process to make the students get the point of what has been conveyed by the teacher. Although there were several dimensions of Communication Strategy implemented by the teacher during the teaching process, the teacher needs to implement it based on the context.) Suggestion for the students (The students are suggested to use more Communication Strategies during the learning process because it can increase the student's participation during the teaching and learning process to get the two-way communications between the teacher and the students.)

\section{CONCLUSION}

Based on the findings described above, the teacher implemented more communication strategies than the students. The implementation of communication strategy in the class was affected by so many aspects, and both came from the teacher and the students. The teacher used more communication strategies to transmit the message to the students and get the result of understanding from the students. And the less implementation of communication strategy by the students can be due to the students' knowledge and the students' activity level.

\section{REFERENCES}

Achim, A. M., Deschamps, I., Loignon, A., Rousseau, L.-S., Fossard, M., \& Tremblay, P. (2021). The neural correlates of referential communication: Taking advantage of sparse-sampling fMRI to study verbal communication with a real interaction partner. Brain and Cognition, 154. https://doi.org/10.1016/j.bandc.2021.105801

Ao, J., Li, N., \& Ma, C. B. (2019). Q-Learning-Based Spinal Code Transmission Strategy in Long Distance FSO 
Communication. Procedia Computer Science, 154. https://doi.org/10.1016/j.procs.2019.06.030

Arsy, H. I., Prasetyo, A. P. B., \& Subali, B. (2020). Predict-Observe-Explain Strategy with Group Investigation Effect on Students ' Critical Thinking Skills and Learning Achievement. Journal of Primary Education, 9(1), 75-83. https://doi.org/10.15294/jpe.v9i1.29109

Asghar, A., Jamil, I., Iqbal, A., \& Yasmin, M. (2018). Learner Attitude towards EFL Learning: A Response from Art and Design. Open Journal of Social Sciences, 06(05), 81-88. https://doi.org/10.4236/jss.2018.65007

Atabekova, A., Lutskovskaia, L., \& Gorbatenko, R. (2021). Developing multiliteracy skills and pragmatic communication awareness of university students learning a foreign language (English) for specific purposes. Thinking Skills and Creativity, 29. https://doi.org/10.1016/j.tsc.2021.100956

Chan, C. S. C. (2021). Helping university students discover their workplace communication needs: An eclectic and interdisciplinary approach to facilitating on-the-job learning of workplace communication. English for Specific Purposes, 64. https://doi.org/10.1016/j.esp.2021.07.002

Chan, J. Y. H. (2021). Bridging the gap between ELF and L2 learners' use of communication strategies: Rethinking current L2 assessment and teaching practices. System, 101. https://doi.org/10.1016/j.system.2021.102609

Coffelt, T. A., Grauman, D., \& Smith, F. L. M. (2019). Employers' Perspectives on Workplace Communication Skills: The Meaning of Communication Skills. Business and Professional Communication Quarterly, 82(4), 418-439. https://doi.org/10.1177/2329490619851119

Davidi, E. I. N., Sennen, E., \& Supardi, K. (2021). Integrasi Pendekatan STEM (Science, Technology, Enggeenering and Mathematic) Untuk Peningkatan Keterampilan Berpikir Kritis Siswa Sekolah Dasar. Scholaria: Jurnal Pendidikan Dan Kebudayaan, 11(1), 11-22. https://doi.org/10.24246/j.js.2021.v11.i1.p11-22

Dumitrescu, C., Olteanu, R. L., Gorghiu, L. M., \& Gorghiu, G. (2014). Learning Chemistry in the Frame of Integrated Science Modules - Romanian Student's Perception. Procedia - Social and Behavioral Sciences, 116(September 2015), 2516-2520. https://doi.org/10.1016/j.sbspro.2014.01.603

Dwi, I. M., Arif, H., \& Sentot, K. (2013). Pengaruh strategi problem based learning berbasis ICT terhadap pemahaman konsep dan kemampuan pemecahan masalah fisika. Jurnal Pendidikan Fisika Indonesia, 9(1), 8-17. https://doi.org/10.15294/jpfi.v9i1.2575

Filgona, J., Filgona, J., \& Linus, K. S. (2017). Mastery Learning Strategy and Learning Retention: Effects on Senior Secondary School Students' Achievement in Physical Geography in Ganye Educational Zone, Nigeria. Asian Research Journal of Arts \& Social Sciences, 2(3). https://doi.org/10.20944/preprints201702.0018.v1

Harrison, A. (2021). Experimental Investigation of Non-Verbal Communication in Eating Disorders. Psychiatry Research, 197. https://doi.org/10.1016/j.psychres.2021.113732

Indah Perawansa, F., Minarni, A., \& Surya, E. (2019). Developing Learning Devices Based on GeoGebra Assisted Discovery Learning with SAVI Approach to Improve Motivation and Mathematical Communication of Senior High School Students MTs Aisyiyah. American Journal of Educational Research, 7(12), 893-900. https://doi.org/10.12691/education-7-12-1

Kembara, Rozak, \& Hadian. (2018). Research-based Lectures to Improve Students' 4C (Communication, Collaboration, Critical Thinking, and Creativity) Skills. Proceedings of the Second Conference on Language, Literature, Education, and Culture (ICOLLITE), 1(1). https://doi.org/10.2991/icollite$18.2019 .50, .20019 .11$.

Kemp, S. E. (2017). RAP: A reading comprehension strategy for students with learning disabilities and concomitant speech-language impairments or ADHD. Journal of Education and Training, 4(2). https://doi.org/10.5296/jet.v4i2.11614

Kusumawati, P., Sudirman, \& Kusuma, P. I. (2017). the Effect of Digital Flashcard on Students 'Vocabulary Mastery of the Fourth Grade Students At Sd Negeri 1 \& 2 Paket Agung in the Academic Year 2016 / 2017. Jurnal Pendidikan Bahasa Inggris Undiksha, 5(2). https://doi.org/10.23887/jpbi.v5i2.13324

Liyana, A., \& Kurniawan, M. (2019). Speaking Pyramid sebagai Media Pembelajaran Kosa Kata Bahasa Inggris Anak Usia 5-6 Tahun. Jurnal Obsesi: Journal of Early Childhood Education, 3(1). https://doi.org/10.31004/obsesi.v3i1.178

Madleňák, R. et al. (2015). Designing a Social Network to Support E-learning Activities at the Department of Communications, University of Žilina. Procedia - Social and Behavioral Sciences, 176, 103-110. https://doi.org/10.1016/j.sbspro.2015.01.449

Megawati. (2016). Kesulitan Mahasiswa Dalam Mencapai Pembelajaran Bahasa Inggris Secara Efektif. Jurnal Pedagogia, 5(2). https://doi.org/10.21070/pedagogia.v5i2.246

Mills, K., Roper, F., \& Cesare, S. (2021). Accelerating student learning in communication and research skills: the adoption of adaptive learning technologies for scenario-based modules. Technology, Change, and the Academic Library, 75. https://doi.org/10.1016/B978-0-12-822807-4.00007-5

Mitchell, B. L., Cuéllar-Partida, G., Grasby, K. L., Campos, A. I., Strike, L. T., Hwang, L. D., Okbay, A., 
Thompson, P. M., Medland, S. E., Martin, N. G., Wright, M. J., \& Rentería, M. E. (2020). Educational attainment polygenic scores are associated with cortical total surface area and regions important for language and memory. NeuroImage. https://doi.org/10.1016/j.neuroimage.2020.116691

Morgan, G., Curtin, M., \& Botting, N. (2021). The interplay between early social interaction, language, and executive function development in deaf and hearing infants. Infant Behavior and Development, 64. https://doi.org/10.1016/j.infbeh.2021.101591

Nakanishi, J., Sumioka, H., \& Ishiguro, H. (2019). A huggable communication medium can provide sustained listening support for special needs students in a classroom. Computers in Human Behavior, 93. https://doi.org/10.1016/j.chb.2018.10.008

Nordin, J. M. (2015). Improving Bedside Communication and Promoting Patient-Centered Care through the Development and Use of Translation Flipbooks. Biology of Blood and Marrow Transplantation, 21(2). https://doi.org/10.1016/j.bbmt.2014.11.655

Nugraha, Purnamasari, I., \& Tanuatmodjo, H. (2016). Interaction Between the Type of School and Learning Outcomes in Student's Soft Skills Enhancement through Cooperative Learning Model (Quasi Experiment on Vocational Students in Bandung). Procedia - Social and Behavioral Sciences, 219. https://doi.org/10.1016/j.sbspro.2016.05.078

Paul, T. D., Malingan, N., \& Angeline, P. M. S. (2020). Intelligent wireless communication establishment with fault-free IoT enabled machine learning strategies. Materials Today: Proceedings, 33(7). https://doi.org/10.1016/j.matpr.2020.06.214

Prihandoko, Y., Slamet, S. Y., \& Winarno. (2017). Cognitive Moral Approach To Civics Education Material Development In The Elementary School. Jurnal Kependidikan, 1(2), 200-2013. https://doi.org/10.21831/jk.v1i2.15279

Putri, I. (2018). Komunikasi Non Verbal (Makna Kinesik) Pesulap Dalam Pertunjukan Sulap Klasik. Jurnal Ilmiah Syiar, 18(1). https://ejournal.iainbengkulu.ac.id/index.php/syiar/article/view/1570

Rafik-Galea, S., Ishak, W. I., \& Marji, A. B. (2012). Library Counter Talk: Communication Encounters between Counter Staff and International Students. Procedia - Social and Behavioral Sciences, 66. https://doi.org/10.1016/j.sbspro.2012.11.243

Sadaf, A., \& Johnson, B. L. (2017). Teachers' Beliefs About Integrating Digital Literacy Into Classroom Practice: An Investigation Based on the Theory of Planned Behavior. Journal of Digital Learning in Teacher Education, 33(4), 129-137. https://doi.org/10.1080/21532974.2017.1347534

Saddhono, K., Sudarsana, I. K., \& Iskandar, A. (2019). Implementation of Indonesian Language the learning Based on Information and Communication Technology in Improving Senior High School Students' Achievement in Surakarta. Journal of Physics: Conference Series, 1254(1). https://doi.org/10.1088/17426596/1254/1/012059

Salim Nahdi, D., \& Cahyaningsih, U. (2018). Pengembangan Perangkat Pembelajaran Matematika Sd Kelas V Dengan Berbasis Pendekatan Saintifik Yang Berorientasi Pada Kemampuan Pemecahan Masalah Siswa. Jurnal Cakrawala Pendas, 5(1), 1-7. https://doi.org/10.31949/jcp.v5i1.1119

Setiyani, Putri, D. P., Ferdianto, F., \& Fauji, S. H. (2020). Designing a Digital Teaching Module Based on Mathematical Communication in Relation and Function. Journal on Mathematics Education, 11(2), 223236. https://doi.org/10.22342/jme.11.2.7320.223-236

Sharif Matthews, J., \& López, F. (2019). Speaking their language: The role of cultural content integration and heritage language for academic achievement among Latino children. Contemporary Educational Psychology, 57, 72-86. https://doi.org/10.1016/j.cedpsych.2018.01.005

Simatupang, H., Purnama, D., \& Simatupang, Z. (2020). The Development of Best Practice Handbook Learning Strategy Based on FlipBook to Support Blended Learning Processes. Journal of Physics: Conference Series, 1462(1). https://doi.org/10.1088/1742-6596/1462/1/012014

Subandi, S., Choirudin, C., Mahmudi, M., Nizaruddin, N., Hermanita, H., \& Hermanita, H. (2018). Building interactive communication with Google Classroom. International Journal of Engineering \& Technology, 7(2.13), 460-463. https://www.sciencepubco.com/index.php/ijet/article/view/18141/8144

Sutarto, S. (2017). Dampak Pengiring Pembelajaran Pendekatan Saintifik Untuk Mengembangan Sikap Spiritual Dan Sosial Siswa. Jurnal Cakrawala Pendidikan, 36(1), 44-56. https://doi.org/10.21831/cp.v36i1.12792

Winatha, K. R., Naswan, S., \& Ketut, A. (2018). Pengembangan E-modul Interaktif Berbasis Proyek Pada Mata Pelajaran Simulasi Digital Kelas X di SMK TI Bali Global Singaraja. Jurnal Teknologi Pembelajaran Indonesia, 8(1). https://doi.org/10.23887/jtpi.v8i1.2238

Wonodipho, A. R. (2019). Establishing Interpersonal Communication And Organizational Climate To Improve Work Motivation. Jurnal Kepemimpinan Pendidikan, 2(1). https://doi.org/10.22236/jkpuhamka.v2i1.3816

Wungguli, D., \& Yahya, L. (2020). Pengaruh Penggunaan Media Berbasis Information and Communication Technology (ICT) terhadap Hasil Belajar Siswa pada Materi Dimensi Tiga. Jambura Journal of Mathematics Education, 1(1), 41-47. https://doi.org/10.34312/jmathedu.v1i1.5376 
Yaniawati, R. P., Indrawan, R., \& Setiawan, G. (2019). Core Model on Improving Mathematical Communication and Connection, Analysis of Students' Mathematical Disposition. International Journal of Instruction, 12(4), 639-654. https://doi.org/10.29333/iji.2019.12441a

Yusnidar. (2014). Penerapan Metode Gallery Walk Untuk Meningkatkan Kemampuan Menulis Teks Analytical Exposition Bahasa Inggris Siswa Kelas XI Ipa-1 Man Model Banda Aceh. Getsempena English Education Journal, 1(2). https://doi.org/10.46244/geej.v1i2.676

Zhang, Y. (2021). Combining computer-mediated communication with data-driven instruction: EFL learners' pragmatic development of compliment responses. The system, 103. https://doi.org/10.1016/j.system.2021.102624 